\title{
Aloe barbadensis: how a miraculous plant becomes reality
}

\author{
Nuria Chinchilla $\cdot$ Ceferino Carrera $\cdot$ \\ Alexandra G. Durán · Mariola Macías • \\ Ascensión Torres $\cdot$ Francisco A. Macías
}

Received: 1 July 2013/Accepted: 28 August 2013/Published online: 11 September 2013

(C) Springer Science+Business Media Dordrecht 2013

\begin{abstract}
Aloe barbadensis Miller is a plant that is native to North and East Africa and has accompanied man for over 5,000 years. The aloe vera plant has been endowed with digestive, dermatological, culinary and cosmetic virtues. On this basis, aloe provides a range of possibilities for fascinating studies from several points of view, including the analysis of chemical composition, the biochemistry involved in various activities and its application in pharmacology, as well as from horticultural and economic standpoints. The use of aloe vera as a medicinal plant is mentioned in numerous ancient texts such as the Bible. This multitude of medicinal uses has been described and discussed for centuries, thus transforming this miracle plant into reality. A summary of the historical uses, chemical composition and biological activities of this
\end{abstract}

N. Chinchilla · C. Carrera · A. G. Durán ·

A. Torres · F. A. Macías $(\varangle)$

Grupo de Alelopatía, Departamento de Química Orgánica, Facultad de Ciencias, Instituto de Biomoléculas (INBIO), Universidad de Cádiz, Campus de Excelencia Internacional Agroalimentario (ceiA3), C/República Saharaui, s/n, 11510 Puerto Real, Cádiz, Spain

e-mail: famacias@uca.es

\section{Macías}

Departamento de Biomedicina, Biotecnología y Salud Pública (Inmunología) y Unidad de Investigación del Hospital Universitario de Puerto Real, Servicio Central de Investigación en Ciencias de la Salud, Instituto de Biomoléculas (INBIO), Edificio Andrés Segovia, C/Dr. Marañón 3, 11002 Cádiz, Cádiz, Spain species is presented in this review. The latest clinical studies involved in vivo and in vitro assays conducted with aloe vera gel or its metabolites and the results of these studies are reviewed.

Keywords Aloe vera Phytochemistry · Acemannan · Bioactivity

\section{Introduction}

The genus Aloe is a plant that has always been included in the Asfodelaceas and lily families. However, in view of their specific and individual characteristics, Aloe has been introduced into a new botanical family named Aloaceas. This family consists of more than 350 species of Aloes registered throughout the world, and new families are discovered each year: from the small Aloe rockery stemless, measuring a few centimeters, to the Aloe arborescent, which can measure several tens of meters (Bassetti and Sala 2001). However, not all of these species are medicinal. The best known Aloes are Aloe vera (Aloe barbadensis Miller), Aloe Socotra Island (Aloe soccotrina Garsault), Cape Aloe (Aloe ferox Miller), Aloe maculate Forssk (Aloe saponaria), Aloe chinensis Steud. ex Baker and Aloe arborescens Miller, all of which have steely barbed characteristics. The most commonly used examples in medicine are the species $A$. 
barbadensis Miller, from which aloe gel and the bitter yellow exudates are obtained, and A. ferox Miller, which provides a bitter yellow juice.

All Aloe species are perennial, leaf-succulent xerophytes (Newton 2001). Xerophytes are plants adapted to survive in areas of low or erratic precipitation and the adaptations may include structural and physiological features. Aloes have thick and fleshy leaves that are enlarged to accommodate the aqueous tissue. The leaf cuticle is thick and is covered with a layer of wax. Most species have groups of cells associated with the vascular bundles, variously called aloin or aloitic cells, which store and perhaps secrete a mixture of compounds with medicinal value. The composition of these secretions varies in different species. This substance appears as an exudate, which is usually yellow, when leaves are broken or cut. Leaves of a few species, such as Aloe fibrosa Lavranos and Newton, have fibers in place of the aloitic cells (Reynolds 2004).

The exact origin of Aloe vera is uncertain, but it seems likely that it is from the Arabian Peninsula, home of the closely related, and possibly conspecific, Aloe officinalis Forssk. The majority of Aloe species occur naturally on mainland Africa in tropical and subtropical latitudes. The genus is found almost throughout the African continent south of the Sahara Desert, except for the moist lowland forest zones and the western end of West Africa. The majority of species occur in southern Africa and on the eastern side of the continent. Many other species are found on the Arabian Peninsula and on Madagascar and a few, mostly formerly in the genus Lomatophyllum, are known on some of the smaller Indian Ocean islands. The Arabian species have clear relationships with the species of northeast Africa. Madagascan species do not appear to be closely related to those of mainland Africa and so active speciation seems to have occurred since the separation of these two land masses. Likewise, the former Lomatophyllum species form a group that is not represented on the African mainland. Some species are very widespread in terms of distribution. Reynolds cites Aloe buettneri A.Berger as the most widespread species, with a range of at least 5,600 km from Mali to Zambia, and the species has since been recorded in Namibia (Reynolds 1966). However, Carter regards this as a West African species only, with two related species in the rest of the range reported by Reynolds (Carter 1994). Another very widespread species is Aloe myriacantha Haw., with a range of about 4,800 km from Kenya and Uganda to the Republic of South Africa. Most other widespread species have more modest distribution ranges, amounting to only hundreds of kilometers. Many countries have some endemic species. The highest rate of endemism is in Madagascar and isolated Indian Ocean islands. Naturally, it is to be expected that very large countries, such as South Africa and isolated islands, such as Madagascar, would have many endemic species. The actual species' distribution has been suggested to be the result of human cultivation (Fig. 1) (DiscoverLife 2013).

Aloe barbadensis is native to Africa and spread to America after expeditions by Columbus and Vespucci owing to maritime trade with the Caribbean. The hot and humid climate of Central America greatly favors the good diffusion of this species, especially in the Caribbean islands, from which its present name barbadensis arises since it originates from Barbados. The correct name is now accepted to be Aloe vera (L.) Burm. f. (Vinson et al. 2005). However, the plant has been known under various names such as Aloe vera, sábila, Curacao Aloe, A. barbadensis Miller or colloquially as Aloe (Reynolds 2004). The first important plantations date from 1870 but it was not until 1920 that this plant was used on a larger scale. Since then this species exploded on a small scale for the extraction of leaf exudates. A. barbadensis is currently the most widely used type of Aloe and it is known worldwide. This is mainly due to the high efficiency of the leaves, to its robustness and ease of pulping for drinks or gels for external use. In fact, the active ingredients in this famous strain cannot be compared, in quantitative terms, to other smaller varieties that are rare and have hardly been exploited from an industrial viewpoint.

Currently the high demand for natural products has triggered a boom in the 'biological' properties and around it a growing industry seeks to sell all manner of low cholesterol, low fat, low calorie, high fiber, omegas, vitamins, etc. The current desire for healthy products has created a new language in which the word 'bio' has flooded the market. As a consequence, prior to the proliferation of products that employ this term in a misleading manner, the authorities forced the removal the word 'bio', which can only be applied when the production is carried out in a completely ecological manner. Aloe vera has not escaped this phenomenon as the number of companies involved in 


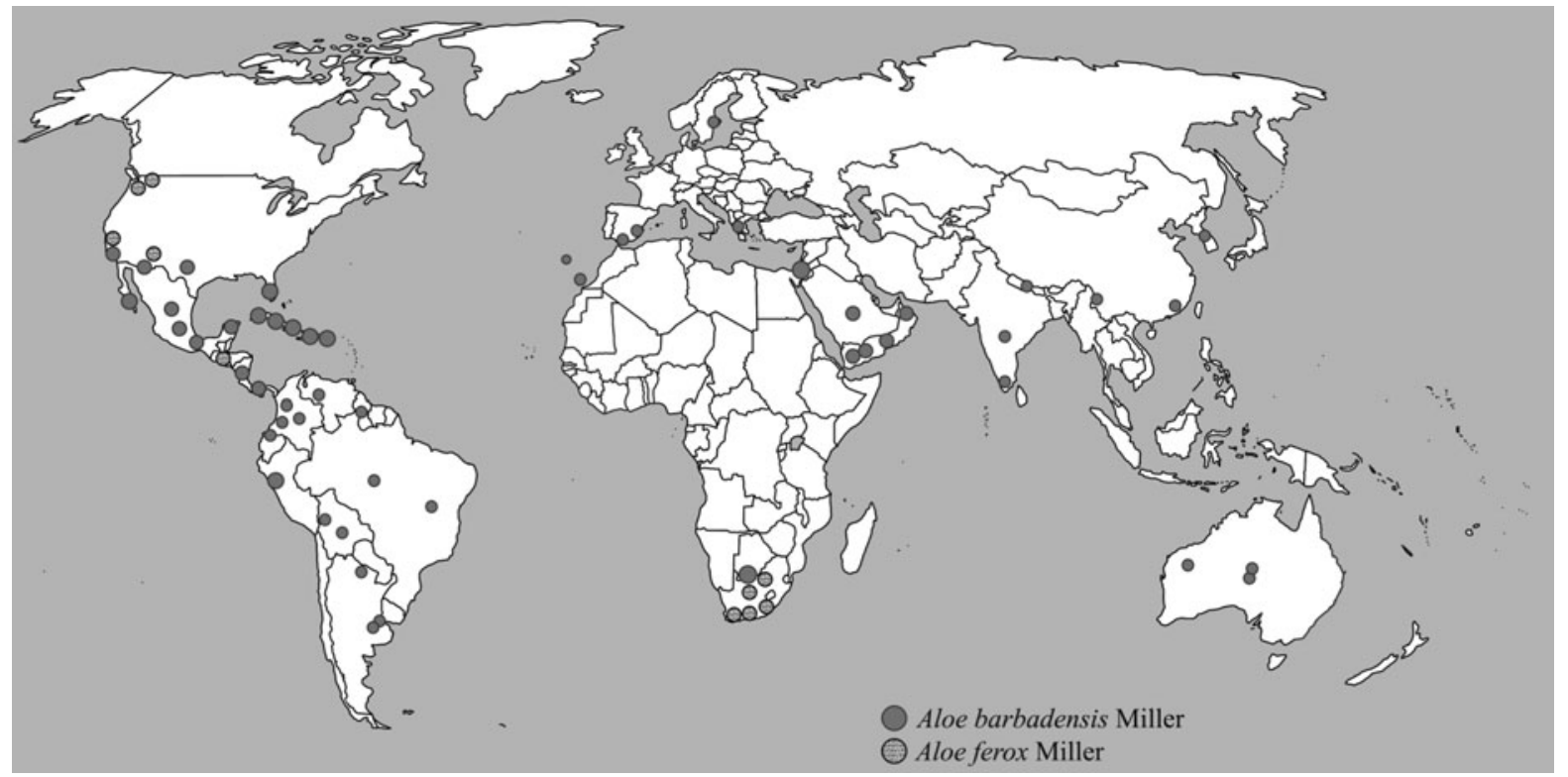

Fig. 1 Global distribution of A. barbadensis and A. ferox

the sale of products derived from this plant has increased markedly and many other completely unrelated companies have taken advantage of this demand to offer yogurts, ice creams, perfumes, mattresses, t-shirts, and even acrylic paint with aloe vera. Regardless of the consumerist frenzy that inevitably unleashes all fads, the aim of this review is to unravel what is true and false about this plant, which some people consider to be almost miraculous, because if it is true that all fashions are passing, it is not a coincidence that all the great ancient cultures knew and used the healing properties of aloe vera.

\section{Historical aspects and traditional uses}

Long known for its mysterious beauty, wild elegance and legendary therapeutic properties, aloe vera was considered as a god in some civilizations. In ancient Egypt, aloe was the plant whose 'blood' offered beauty, health and eternal life. Aloe was part of the ritual of embalming and accompanied the Pharaoh on his journey to the other world. For mythical emperors of China, aloe's healing thorns personified the sacred nails of Divinity. For the Indians of the New World, aloe was one of the 16 sacred plants worshiped as gods. In Africa, the camel-herding nomads called it the 'lily of the desert', the Americans 'the silent healer' or
'Doctor Aloe', and Russians the 'elixir of life', amongst others.

The name Aloe vera is derived from the Arabic word alloeh, which means 'shining bitter substance', while vera in latin means 'truth'. The first credible human testimony concerning aloe was found in Egypt, from about $3000 \mathrm{BC}$, and this consists of pictorial representations adorning tombs and funerary monuments. The oldest epigraphic document concerning the medicinal use of aloe vera appears on baked clay tablets from Sumeria, and these were written before $2100 \mathrm{BC}$ and they describe in cuneiform the laxative properties of the plant. Despite the fact that aloe has been cited in previous texts, such as the codices of Emperor Shon-Nung (about 1800 BC) or Babylonian tablets from the same era, the Ebers papyrus or Egyptian Book Remedies (1550 BC) are considered to be the first medical compendium to contain formulas for making elixirs with aloe juice (Swanson 1995).

Aloe also had the reputation of being able to preserve beauty and women's splendor in ancient Egypt. The Pharaohs considered it to be an elixir of long life. Tradition demanded that a staff of aloe was carried as a symbol of rebirth as a present during funeral ceremonies. Aloe was planted around the pyramids and along the roads leading to the Valley of the Kings and it accompanied the Pharaoh in his transit to the afterlife in order to care for and feed him during 
his journey. When aloe bloomed, it was taken as a sign that the deceased had happily reached the 'other shore' (Schweizer 1994).

Moreover, aloe was a symbol of beauty, patience, luck and health for the Greeks. Hippocrates described some medicinal properties of aloe, including the ability to promote hair growth, as a cure for tumors and for the relief of dysentery and stomach-ache. For the Egyptians, aloe was considered as the plant of immortality and today it is still considered to be an emblem of happiness and protection and is often found in the inside of houses to absorb negative energies. Recent studies have shown that the aloe plant is capable of removing more than $94 \%$ of formaldehyde in a closed space in just 4 days and it also shows excellent absorption power against volatile organic compounds, which are major components of environmental pollution (Yau et al. 2011).

It is believed that, around $330 \mathrm{BC}$, Alexander the Great was shot with an enemy arrow in the siege of Gaza (Palestine). He saw how his wound became infected during the conquering advance through Egypt and the Libyan Desert. A priest sent by the celebrated Aristotle (his tutor and mentor), smeared the wound with an oil made from aloe that came from the island of Socrota. His injury was cured. It seems that Alexander the Great undertook a naval expedition to take over Socrota's Island and its aloe plantations with the encouragement of Aristotle. Indeed, it was even claimed that the juice of this plant made warriors invulnerable (Evans 1989).

Since the earliest times, in the Middle East and Africa, the Bedouin people from the Arabian Peninsula and the Tuareg warriors from the Sahara called aloe the 'Desert Lily'. In order to protect their homes, the inhabitants of Mesopotamia decorated their doors with aloe leaves. In case of an epidemic or famine, Parsees and the Scythians had the custom of feeding on aloe pulp.

It was not until the middle Ages and the Renaissance when Christian warriors discovered the properties of aloe during the Crusades as it was considered to be a panacea for their Muslim adversaries. Arabs introduced aloe into Andalusia during their conquests in Europe. The Muslim name for aloe is saber and this signifies patience, a term that refers to the period between burial and resurrection (Grieve 1998).

The use of aloe pulp enabled Spanish sailors to be partially protected from diseases and malnutrition.
These properties led Christopher Columbus to call it the 'potted doctor'. Consequently, the Spanish always transported aloe aboard their ships. Paracelsus, the great physician of the Renaissance period, discovered the merits of aloe in Salerno and this reputation was later exported to Spain and Portugal. Paracelsus sent a letter in which he refered to aloe in veiled words such as 'mysterious and secret aloe whose golden aloe juice cures burns and blood poisoning'. In particular, Portuguese and Spanish Jesuits, following in the footsteps of the early explorers, cultivated aloe in all of the colonies of America, Africa and the Far East as a plant that had known curative properties.

In Japan aloe is known as a 'queen plant'. Tens of species are cultivated for multiple uses. The plant extracts are made into drinks and food due to the medicinal properties of the plant in all its forms. In ancient times, the samurai body was smeared with the pulp of aloe before a battle in order to expel demons and to make the warriors immortal. Nowadays, $A$. saponaria pulp is used to make soaps and cosmetics. Likewise, A. ferox, Aloe thraskii Baker and Aloe marlothii A.Berger are used as components in numerous pharmaceutical and cosmetics preparations.

Aloe is used in a wide range of forms in China. The Chinese pharmacopoeia of Li Shih-Shen (1518-1593) cites aloe amongst the plants with the highest therapeutic properties and it was called the 'harmony remedy'.

This multipurpose plant has been used since time immemorial and today it is still used extensively worldwide and has become a popular household remedy, exhibiting a range of beneficial healthpromoting properties. The traditional use of natural ingredients, which was largely based on empirical evidence and folk medicine recipes, has been completely updated and scientifically validated by recent bench and clinical research. An increasing body of scientific data now supports the use of aloe in various clinical settings and new indications are continuously emerging. All of these findings may help to provide a foundation for further studies and the development of more controlled processing and applications for this widely accepted medicinal plant.

A review of historical aspects and traditional uses of this coveted ethnomedicinally and pharmacology important species is presented along with a discussion of the chemical composition and biological properties. These 'new naturals' are expanding our choices for the 
management and treatment of different disorders on an ongoing basis, with new and emerging usage and research data supporting their strong reputation as safe and effective options.

\section{Chemical composition}

The aloe plant has elongated and pointed leaves. Each leaf consists of two parts, an outer green rind and an inner clear pulp. The pulp is the major part of the leaf by volume and it appears to be clear and mucilaginous. It is this part of plant that has been most widely used for therapeutic purposes. Acemannan Immunostimu$1 \mathrm{n}^{\mathrm{tk}}$, a pulp extract rich in mannan, has been licensed for the treatment of fibrosarcoma in cats and dogs. The pulp has been described using several other terms, including inner gel, mucilaginous gel, mucilaginous jelly and leaf parenchyma. A range of biological activities, including anti-viral, anti-bacterial, laxative, protection against radiation, anti-inflammatory and immunostimulation have been attributed to this plant-particularly its polysaccharides.

When the leaves of most species of Aloe are cut a more or less copious exudate appears, which is yellow at first but rapidly darkens to brown or, in a few species, dark red. These exudates contain phenolic compounds that can be distinguished chromatographically. Most of the exudate compounds identified to date are chromone, anthraquinone or anthrone derivatives. Some compounds are widespread in the genus and some are confined to a few species and are therefore of potential chemotaxonomic value. These phenolics do not occur in the parenchyma cells within the leaf, where polysaccharides and glycoproteins are characteristic. The exudate has a high content of aloin ( $>28 \%$ wet basis), which is a C-glucoside of aloeemodin anthrone (Reynolds 2004). This substance has pharmaceutical uses as a laxative (Ramachandra and Srinivasa Rao 2008).

\section{Gel structure and composition}

$\mathrm{Ni}$ et al. showed that the two distinct parts of the leaf, i.e. the outer green rind and inner clear pulp, were clearly visible. Vascular bundles are tubular structures located in the pulp and these are adjacent to the green rind. The number of these bundles varied depending on the size of leaves (Fig. 2). The majority of the pulp
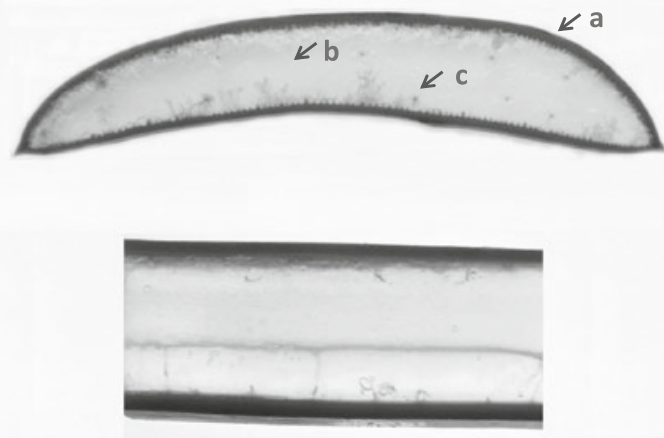

Fig. 2 Gross view of Aloe vera leaf sections: $a$ the rind, $b$ the pulp and $c$ the vascular bundle

consists of water, with the dry matter only accounting for $0.9 \%(\mathrm{w} / \mathrm{w}, \mathrm{SD}=0.33)$. Examination of sections (2-3 mm) of fresh leaves showed that the pulp consists of large clear mesophyll cells with a hexagonal or elongated hexagonal shape. The aforementioned cells are very large and some are more than $1,000 \mu \mathrm{m}$ (or $1 \mathrm{~mm}$ ) long. The walls of these cells are transparent. The cell walls could be clearly seen under higher magnification. Electron microscopy revealed that, in addition to cell walls, only the cell membranes and a very limited number of cellular organelles are present in the pulp. Intact cellular organelles such as nuclei, chloroplasts and mitochondria were only observed in the green rind and vascular bundles. Thus, these mesophyll cells in the pulp appeared to be non-living cells and they probably play a role in water storage $(\mathrm{Ni}$ et al. 2004).

The carbohydrate composition of the pulp has been described in numerous reports. Various polysaccharides have been detected or isolated from the pulp, including mannan (Segal et al. 1968; Yagi et al. 1977, 1986; Waller et al. 1978; Gowda et al. 1979; RadjabiNassab et al. 1984; 'T Hart et al. 1989), galactan (Mandal and Das 1980b), arabinan (Mandal and Das 1980a), arabinorhamnogalactan (Mabusela et al. 1990), pectic substance (Rowe and Parks 1941; Ovodova et al. 1975; Mandal and Das 1980a, b) and glucuronic acid-containing polysaccharide (Hranisavljevic-Jakovljevic and Miljkovic-Stojanovic 1981; Wozniewski et al. 1990). However, significant variations in the pulp polysaccharide species were found in some studies. For example, in several studies mannan was identified as the major polysaccharide in the pulp, whereas in other studies, in the absence of 
Fig. 3 Acemannan structure
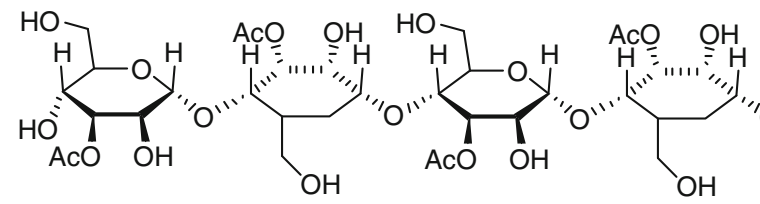

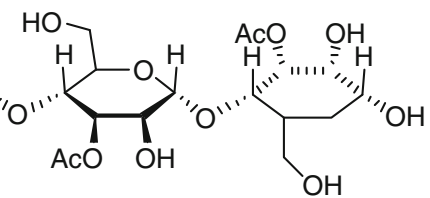

mannan, a pectic substance was identified as the primary polysaccharide (Rowe and Parks 1941; Ovodova et al. 1975; Mandal and Das 1980a, b; Mabusela et al. 1990). The reason for such discrepancies was not understood but was largely attributed to seasonal changes and/or different geographic locations (Mandal and Das 1980b; Grindlay and Reynolds 1986b). Mannan is the most widely studied polysaccharide from A. barbadensis. This compound consists of $\beta 1-4-$ linked mannose residues (Yagi et al. 1977, 1984; Paulsen et al. 1978; Gowda et al. 1979; Mandal and Das 1980b; Radjabi-Nassab et al. 1984; Vilkas and Radjabi-Nassab 1986; Manna and McAnalley 1993). Mannan is partially acetylated at the C-2 and C-3 positions and thus the term acemannan was coined (Manna and McAnalley 1993). Mannan also contains some side chains - mainly galactose - attached to C-6 (Fig. 3).

The $\beta$-(1 $\rightarrow 4)$-glycosidic bond configuration of acemannan is an important consideration in terms of the therapeutic effects of aloe vera gel, since humans lack the ability to enzymatically break down these bonds (Boudreau and Beland 2006). The acemannan found in aloe is structurally unique and this makes it a characteristic compound of aloe species amongst other well-known plant mannans (which have distinct sidechains or are not acetylated and are insoluble) (Ian and Yawei 2004).

\section{Malolyl glucans}

Three malic acid acylated carbohydrates were isolated from aloe vera gel and these were characterized as veracylglucan A (6- $O$-(1-L-maloyl)- $\alpha-, \beta-\mathrm{D}-\mathrm{Glc} p)$, veracylglucan B ( $\alpha$-d-Glcp- $(1 \rightarrow 4)-6-O$-(1-L-maloyl) $-\alpha-, \beta-\mathrm{D}-\mathrm{Glc} p)$ and veracylglucan C ( $\alpha$-D-Glcp- $(1 \rightarrow 4)$ -tetra-[6-O-(1-L-maloyl)- $\alpha$-D-Glcp- $(1 \rightarrow 4)]-6-O-(1-$ L-maloyl)- $\alpha-, \beta-\mathrm{D}-\mathrm{Glc} p$ ) (Fig. 4).

\section{Chromones}

Most of the chromones described to date from aloe leaf exudates are derivatives of 8 - $C$-glucosyl-7-hydroxy- 5-methyl-2-propyl-4-chromone. The variations arise from the degree of oxidation in the propyl side-chain, methylation of the hydroxyl group on C7 and esterification of the glucose moiety.

Aloesone was reported as a minor component of aloe vera (Holdsworth 1972). Aloesin, which could be regarded as the parent compound of the aloe chromones, was described first (Haynes et al. 1970) and is widespread throughout the genus, occurring in $35 \%$ (Reynolds 1985) or $46 \%$ (Rauwald and Niyonzima 1991) of species examined and often in a significant quantity. A variant with the $\mathrm{C}$-glucosyl residue in the furanose form has been described as neoAloesin A (Park et al. 1996). Esterification of the glucose moiety has been observed with cinnamic acid (Fig. 5).

Reduction of the keto group on carbon 10 gives rise conceptually to another series of compounds that are derivatives of aloesol (Okamura et al. 1997a), some of which have been recognized in A. barbadensis. The 8- $C$-glucoside of the 2-methyl derivative has also been found and the structure is shown in Fig. 6 (Okamura et al. 1996, 1998; Lv et al. 2008).

The reduction of the hydroxyl group at position 10 generates another family of skeletons and the compounds that have been isolated include aloeresin $\mathrm{G}$ (Xiao et al. 2000) and C-2'-decoumaroyl-aloeresin G. The latter product, along with allo-aloeresin $\mathrm{D}$, showed activity against the enzyme $\beta$-secretase (BACE 1), which has been recognized as a valuable target for the treatment of Alzheimer's disease ( $\mathrm{Lv}$ et al. 2008). Recently, two new chromones have been isolated (Wu et al. 2012) with a new skeleton (Fig. 7). Furthermore, oxidation of the propyl side-chain to give a propanediol structure was observed in aloe compounds.

\section{Anthraquinones}

Anthraquinones are tricyclic aromatic quinones that are yellow, orange or red in color (Lee et al. 2012). Several anthraquinones have been isolated from the dried latex of the leaves of aloe vera. Some of these compounds, such as aloe-emodin, physcion, 
Fig. 4 Malolyl glucans isolated from A. barbadensis<smiles>O=C(O)CC(O)C(=O)OCC1(CO)O[C@@H](O)C(O)C(O)C1O</smiles>

Veracylglucan A<smiles>O=C(O)CC(O)C(=O)OCC1(CO)C(O)C(O)C(O)C(O)C(O)C(O)C1O</smiles>

Veracylglucan B

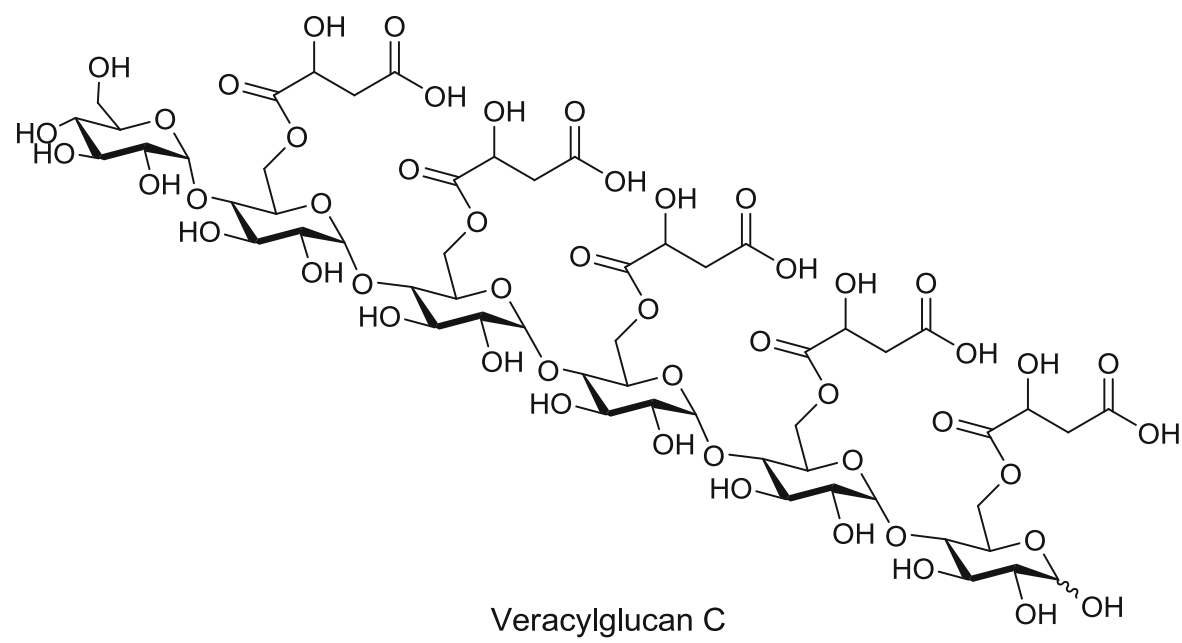

crysophanol, emodin and rhein, among others, are shown below (Meng et al. 2004; Ashnagar et al. 2006; Hsu and Chung 2012) (Fig. 8).

\section{Tetrahydroanthracenones}

Compounds in which the C-ring is reduced are named tetrahydroanthracenones. Two compounds have been isolated from aloe vera (Fig. 9): aloechrysone (isolated from the fresh sap of the leaves) and aloebarbendol (isolated from roots) (Saleen et al. 1997). In addition, 4-O-glucosides of aloesaponols III and IV have been isolated from the callus tissue of $A$. barbadensis (Yagi et al. 1998). It has been demonstrated that these compounds are usually found in the roots along with some anthraquinones (Reynolds 2004).

\section{Anthrones}

Anthranoids, in particular diastereomic anthrone $C$-glycosides, are characteristic secondary products in the genus Aloe. They occur in the leaf exudates of more than $60 \%$ of the examined species (Sigler and Rauwald 1994). One of the main phytoconstituents of aloe vera is aloin (Fig. 10). This compound occurs naturally as a mixture of diastereomers and is a $C$-glucoside of aloe-emodin anthrone found in the outer rind of the aloe plant. Both compounds are widely used for their cathartic properties and as bittering agents in alcoholic beverages.

This glycoside has a yellow fluorescence and plays an important part in the defense mechanisms against herbivores. The levels of aloin in leaves are highly variable and they depend on the part of the leaf, age and growing conditions. The aloin content is higher in young leaves that in older leaves. On the other hand, aloin has been reported to constitute up to $30 \%$ dried leaf exudates of the aloe plant (Patel et al. 2012).

Other anthrone $C$-glycosides obtained from the bitter yellow juice of aloe leaves are shown in Fig. 11 (Rauwald 1990; Okamura et al. 1997b; Park et al. 1998; Saccu et al. 2001; Fanali et al. 2010; Lee et al. 2012; Wu et al. 2013). 
Fig. 5 Aloesone and its derivatives<smiles>CC(=O)Cc1cc(=O)c2c(C)cc(O)cc2o1</smiles>

Aloesone<smiles>CC(=O)Cc1cc(=O)c2c(C)cc(O)c(C3O[C@H](CO)[C@@H](O)[C@H](O)[C@H]3O)c2o1</smiles>

Aloesin (Aloeresin B)<smiles>CC(=O)Cc1cc(=O)c2c(C)cc(O)c([C@@H]3OC([C@H](O)CO)[C@@H](O)[C@H]3O)c2o1</smiles>

Neoaloesin A<smiles></smiles>

Aloeresin F<smiles>CC(=O)Cc1cc(=O)c2c(C)cc(OC3O[C@H](CO)[C@@H](O)[C@H](O)[C@H]3O)c(C3O[C@@H](CO)[C@@H](O)[C@H](O)[C@H]3OC(=O)/C=C/c3ccc(O)cc3)c2o1</smiles>

Aloeresin C

A diglycoside of $O$-methoxy-nataloe-emodin-8methyl ether from aloe vera has been described and is named homonataloside $\mathrm{B}$, which was isolated from the leaf exudate (Viljoen et al. 2002) (Fig. 12). Two other anthraquinone dimers have also been isolated from ethanolic extracts of aloe vera (Conner et al. 1990; Yang et al. 2010).

Phenolic compounds

Phenolic compounds are widespread in plants and are responsible for a multitude of biological activities. The following compounds have been identified in the skin of the leaves: sinapic acid, quercitrin, kaempferol, apigenin, gallic acid, protocatechuic acid, catechin, vanillic acid, epicatechin, syringic acid, chlorogenic acid, gentisic acid, caffeic acid, coumaric acid, ferulic acid, rutin, miricetin and quercetin. With the exception of quercetin, all of these compounds have also been identified in the flowers of the plant (Lopez et al. 2013). Leaf skin extracts were characterized by the abundance of catechin, sinapic acid and quercitrin. Gentisic acid, epicatechin and quercitrin were the most prominent phenolic compounds in the flowers.
Another dimeric compound isolated from the roots of aloe vera consisted of two 4-hydroxy-6-methoxybenzopyran moieties (Fig. 13) joined by a $\mathrm{C}-\mathrm{C}$ bond (Saleem et al. 1997) and this is distantly related to the chromones. Feralolide, isolated as a minor component of Cape aloes, was shown to be a dimer with a methylene bridge of 2,4-dihydroxyacetophenone and 6,8-dihydroxyisocoumarin (Speranza et al. 1993). This compound was subsequently found in aloe vera (Choi et al. 1996).

\section{Sterols}

The common plant sterol $\beta$-sitosterol was found in whole aloe vera leaves and it was accompanied by smaller amounts of cholesterol, ampestrol and lupeol (Waller et al. 1978). Sitosterol glucoside and its palmitic acid ester were subsequently found in whole leaves of aloe vera, once again in conjunction with lupeol (Kinoshita et al. 1996). A later study also showed $\beta$-sitosterol and a variety of n-alkanes in the gel of aloe vera with $n$-octadecane predominating along with fatty acids and their methyl esters (Yamaguchi et al. 1993) (Fig. 14). Recently five 
<smiles>Cc1cc(O)cc2oc(CC(C)O)cc(=O)c12</smiles>

Aloesol<smiles>Cc1cc(O)c([C@@H]2O[C@H](CO)[C@@H](O)[C@H](O)[C@H]2OC(=O)/C=C\c2ccc(O)cc2)c2oc(C[C@H](C)O)cc(=O)c12</smiles>

Isoaloeresin D<smiles>Cc1cc(O)c([C@@H]2O[C@H](CO)[C@@H](O)[C@H](O)[C@H]2O)c2oc(CC(C)O)cc(=O)c12</smiles>

Aloesinol<smiles>COc1cc(C)c2c(=O)cc(CC(C)O)oc2c1[C@H]1O[C@H](CO)[C@@H](O)[C@H](O)[C@H]1O</smiles>

7-O-methylaloesinol<smiles>COc1cc(C)c2c(=O)cc(C[C@H](C)O)oc2c1[C@H]1O[C@H](CO)[C@@H](O)[C@H](O)[C@H]1OC(=O)/C=C/c1ccccc1</smiles>

Aloeresin $\mathrm{E}$<smiles>COc1cc(C)c2c(=O)cc(C[C@H](C)O)oc2c1[C@H]1O[C@H](CO)[C@@H](O)[C@H](O)[C@H]1OC(=O)/C=C/c1ccc(O)cc1</smiles>

Aloeresin D<smiles>C=CC(=O)O[C@H]1[C@H](c2c(OC)cc(C)c3c(=O)cc(C[C@H](C)O)oc23)O[C@H](CO)[C@H](O)[C@H]1O</smiles>

Allo-aloeresin D<smiles></smiles>

4'-O-glucosyl-isoaloeresin DI<smiles></smiles>

4'-O-glucosyl-isoaloeresin DII

Fig. 6 Aloesol and its derivatives

phytosterols have been identified and these were isolated from the fresh leaf gel in a $\mathrm{CHCl}_{3} / \mathrm{MeOH}$ extract (Tanaka et al. 2006).

\section{Metals}

In addition to the organic compounds discussed above, several studies have been carried out to determine the inorganic components of the aloe plant. The most important study concerns the determination of metals in the plant, with the same three parts considered: skin, filet and gel. The gel was obtained when the filets were extruded and the remaining fibrous fraction was discarded. $\mathrm{Ca}, \mathrm{K}, \mathrm{Na}$ and $\mathrm{Mg}$ were the predominant mineral elements in all the aloe fractions. In particular, $\mathrm{Ca}$ was the main mineral element in all fractions except in the gel, in which $\mathrm{Na}$ and $\mathrm{K}$ were detected in higher quantities (Femenia et al. 1999). Robson et al. pointed out that the presence of $\mathrm{K}$ in different concentrations may regulate the healing properties of aloe vera. Other elements, such as $\mathrm{Fe}, \mathrm{Cu}, \mathrm{Zn}$ and $\mathrm{P}$, were detected in minor amounts (Robson et al. 1982).

Germanium is one of the trace elements present in aloe vera and this warrants further mention due to its many health benefits. Germanium is found in revitalizing plants such as ginseng and ginger. Carboxyethylgermanium sesquioxide (Ge-132) or organic germanium (Fig. 15) has various biological activities and is indicated for many diseases. The mode of action of this chemical is an increase in lymphocyte production NKlo, which causes activation of the immune system and destroys all cells and tumor malfunctions. 
<smiles></smiles>

Aloeresin $\mathrm{G}$<smiles>C[C@H](O)CC(=O)Cc1cccc2oc(COC3O[C@H](CO)[C@@H](O)[C@H](O)[C@H]3O)cc(=O)c12</smiles>

5-((S)-2'-oxo-4'-hydroxypentyl)-2(ß-glucopyranosyl-oxy-methyl) chromone<smiles></smiles>

C-2'-decoumaroyl-aloeresin G<smiles>COc1ccc2c(=O)cc(C(O)C(C)O)oc2c1[C@@H]1O[C@H](CO)[C@@H](O)[C@H](O)C1O</smiles>

7-O-Methylaloesindiol<smiles>COc1ccc2c(=O)cc([C@@H](O)[C@H](C)O)oc2c1[C@H]1O[C@H](CO)[C@@H](O)[C@H](O)C1OC(=O)/C=C/c1ccccc1</smiles>

2'-O-Cinnamoyl-7-O-methyl-aloesindiol A<smiles>COc1ccc2c(=O)cc([C@H](O)[C@H](C)O)oc2c1[C@H]1O[C@H](CO)[C@@H](O)[C@H](O)C1OC(=O)/C=C/c1ccccc1</smiles>

2'-O-Cinnamoyl-7-O-methyl-aloesindiol B

Fig. 7 Other chromones from A. barbadensis

Aloe leaves have a total concentration of germanium of $1219.50 \mathrm{ng} / \mathrm{g}$, of which $98.99 \%$ is organic germanium (McMahon et al. 2006).

\section{Bioactivity studies}

As mentioned above, the aloe plant has been used as a popular therapeutic resource since ancient times. These uses are reflected in the main areas of study that concern aloe vera. Almost $80 \%$ of the publications are in the area of medicine and pharmacology, followed by agriculture, biochemistry and chemistry. The interest in the scientific community for Aloe and its many properties has increased in recent years-as can be seen in Fig. 16, which shows how the number of publications in which aloe vera is mentioned has increased in recent years (Scopus 2013). This review provides an overview of the multiple biological activities that have been described for this plant.

Antitumoral activity

Over 4,000 studies have been performed on the effectiveness of aloe vera in medical treatment and some of these addressed its role in recovery from diagnosed cancer. Basic research over the past couple of decades has started to reveal the extent of aloe's 
Fig. 8 Anthraquinones isolated from A. barbadensis<smiles>Cc1cc(O)c2c(c1)C(=O)c1cccc(O)c1C2=O</smiles>

Crysophanol<smiles>O=C1c2cccc(O)c2C(=O)c2c(O)cc(CO)cc21</smiles>

Aloe-emodin<smiles>Cc1cc(O)c2c(c1)C(=O)c1cc(O)cc(O)c1C2=O</smiles>

Emodin<smiles>O=C1c2c([N+](=O)[O-])cc([N+](=O)[O-])c(O)c2C(=O)c2c1c([N+](=O)[O-])c(O)c(CO)c2[N+](=O)[O-]</smiles>

Aloetic acid<smiles>CC(=O)c1c(O)cc2c(c1C)C(=O)c1c(O)cccc1C2=O</smiles>

Aloesaponarin I<smiles>O=C(O)c1cc(O)c2c(c1)C(=O)c1cccc(O)c1C2=O</smiles>

Rhein<smiles>O=C1c2c(O)cccc2Cc2cc(CO)cc(O)c21</smiles>

Aloe-emodin-9-anthrone<smiles>COc1cc(O)c2c(c1)C(=O)c1cc(C)cc(O)c1C2=O</smiles>

Physcion<smiles>O=C1c2cccc(O)c2C(=O)c2cccc(O)c21</smiles>

Danthron<smiles>COc1cccc2cc3c(c(O)c12)C(=O)C[C@](C)(O)C3</smiles>

Aloechrysone<smiles>Cc1cc(O)c2c(O)c3c(cc2c1)CC[C@H](O)C3=O</smiles><smiles>[O]C1O[C@@H](O)[C@@H](O)[C@H](O)[C@H]1CO</smiles><smiles>Cc1c2c(cc3c(O)cc(O)cc13)C[C@@H](O)CC2=O</smiles>
Aloebarbendol<smiles>CO[C@H]1CCc2cc3cc(C)cc(O)c3c(O)c2C1=O</smiles><smiles>COC1O[C@H](O)[C@@H](O)[C@H](O)[C@H]1CO</smiles>

4-O-glucoside aloesaponol III 4-O-glucoside aloesaponol IV

Fig. 9 Tetrahydroanthracenones isolated from aloe vera

pharmaceutical potential, particularly against neoplastic disease (Harlev et al. 2012). Aloe plants exhibit anticancer activity in vitro and in vivo. The antineoplastic properties are due to at least three different mechanisms based on antiproliferative, immunostimulatory and antioxidant effects. The antiproliferative action is determined by anthracenic and anthraquinonic molecules such as aloe-emodin, aloesin and<smiles>O=C1c2c(O)cccc2[C@@]2(CO[C@H](CO)[C@@H](O)[C@@H](O)[C@@H]2O)c2cc(CO)cc(O)c21</smiles>

Aloin A (Barbaloin)<smiles>C[C@@]1([C@@H]2c3cccc(O)c3C(=O)c3c(O)cc(CO)cc32)O[C@H](CO)[C@@H](O)[C@H](O)[C@H]1O</smiles>

Aloin B (Isobarbaloin)

Fig. 10 Aloin isolated from the leaf exudates

aloin, which are present in the gel of the aloe vera leaf, while the immunostimulating activity is mainly due to acemannan, a mucopolysaccharide of aloe vera gel that displays antitumor activities in vitro through the activation of immune responses (Zhang and Tizard 1996).

The majority of the studies conducted to date have focused on acemannan, which is attributed to various biological activities including immunomodulatory and antitumor (Tizard and Ramamoorthy 2004). The anticancer biological mechanism of acemannan may be exerted through pluripotent effector cells, such as macrophages, as aloe extracts are known to induce macrophage activity (Zhang and Tizard 1996). 


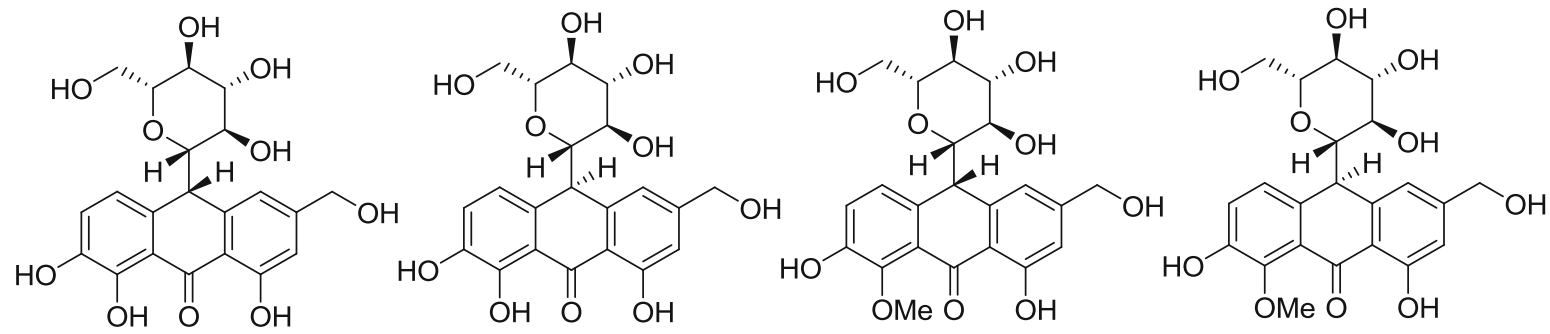

7-hydroxyaloin A

7-hydroxyaloin B

8-O-methyl-7-hydroxyaloin A 8-O-methyl-7-hydroxyaloin B

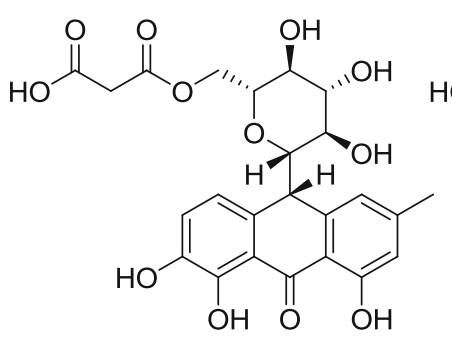

$6 `$-malonylnataloin A<smiles>Cc1cc(O)c2c(c1)[C@H](C1O[C@@H](COC(=O)CC(=O)O)[C@H](O)[C@H](O)[C@H]1O)c1ccc(O)c(O)c1C2=O</smiles>

6'-malonylnataloin B<smiles>C[C@]12c3cccc(O)c3C(=O)[C@H]1O[C@H](CO)[C@H](O)[C@H](O)[C@H]2O</smiles>

10-hydroxyaloin A<smiles>COc1ccc(O)c2c1C(=O)c1c(O)cc(CO)cc1[C@@]2(O)[C@]1(O)O[C@H](CO)[C@@H](O)[C@H](O)[C@H]1O</smiles>

10-hydroxyaloin B

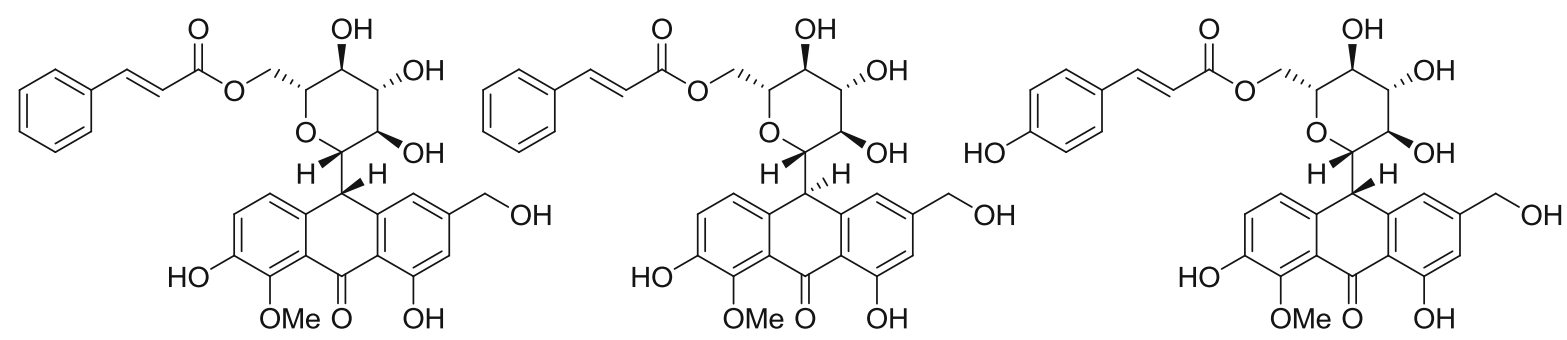

8-O-methyl-7-hydroxyaloin A 8-O-methyl-7-hydroxyaloin B $\quad 6$ '-O-p-Coumaroyl-7-hydroxyaloin A

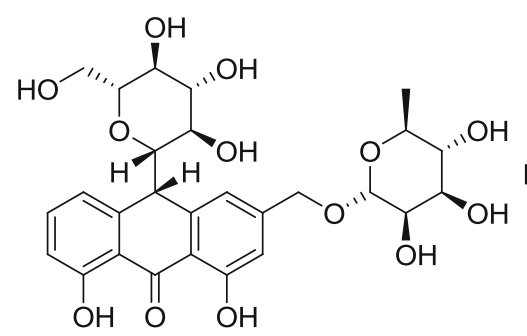

Aloinoside $\mathrm{A}$<smiles>CCOC(C)C</smiles>

Aloinoside B

Fig. 11 Anthrone $C$-glycosides isolated from the bitter exudate of aloe leaves

Clinical studies have even been carried out on dogs and cats with spontaneous tumors and the animals were treated with acemannan by intraperitoneal and intralesional routes of administration (Harris et al. 1991). Similar studies have also been conducted on humans. The study included 50 patients suffering from lung cancer, gastrointestinal tract tumors, breast cancer or brain glioblastoma. The patients were treated with melatonin (MLT) alone or melatonin plus aloe vera tincture. This preliminary work suggested 
<smiles>COc1c(O)ccc2c1C(=O)c1c(OC3O[C@H](CO)[C@@H](O)[C@H](O)[C@H]3O)cc(C)cc1C2OC1O[C@H](CO)[C@@H](O)[C@H](O)C1O</smiles>

Homonataloside B

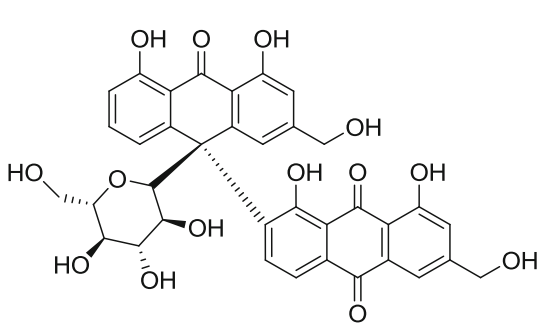

Elgnica dimer $\mathrm{A}$<smiles>O=C1c2cc(CO)cc(O)c2C(=O)c2c1ccc([C@]1([C@H]3O[C@H](CO)[C@@H](O)[C@H](O)[C@H]3O)c3cccc(O)c3C(=O)c3c(O)cc(CO)cc31)c2O</smiles>

Elgnica dimer B

Fig. 12 Homonataloside B and glycosylated anthraquinones obtained from aloe vera<smiles>COc1ccc2c(c1)C(O)C(C1COc3ccc(OC)cc3C1O)CO2</smiles>

bis-benzopyran

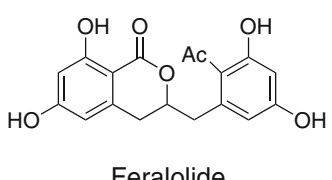

Feralolide
Fig. 13 Phenolic compounds from aloe vera
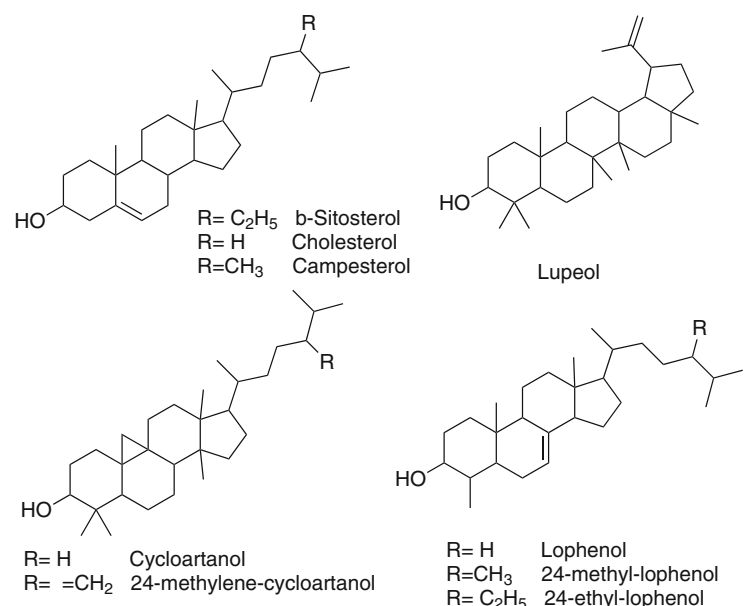

Fig. 14 Sterols from aloe vera<smiles>O=C(O)CC[Ge](=O)O[Ge](=O)CCC(=O)O</smiles>

Ge-132

Fig. 15 Carboxyethylgermanium sesquioxide (Ge-132)

that natural cancer therapy with MLT plus aloe vera extracts may produce therapeutic benefits, at least in terms of stabilization of the disease and survival, in patients with advanced solid tumors for whom no other standard effective therapy is available (Grindlay and Reynolds 1986a).

The antiproliferative and cytotoxic potential of the natural anthracycline aloin from aloe vera was tested on human uterine carcinoma HeLaS3 cells. Aloin showed a pronounced antiproliferative effect at physiological concentration, caused cell cycle arrest in the $\mathrm{S}$ phase, and markedly increased HeLaS3 cell apoptosis. These results indicate that aloin, due to its less undesirable side effects and anti-metastatic potential, may be the agent of choice for clinical protocols for the treatment of human cervical carcinoma in the future (Niciforovic et al. 2007).

The aglycone of aloin, aloe-emodin, also has antitumor activities (Acevedo-Duncan et al. 2004). There are numerous studies on aloe-emodin in vitro, in vivo and in clinical studies. The anticancer effect of aloe-emodin in vitro was tested on two human colon carcinoma cell lines, DLD-1 and WiDr (Lin and Uen 2010). This compound induced cell death in a dose-dependent and time-dependent manner. Notably, the WiDr cells were more sensitive to aloeemodin than the DLD-1 cells. Aloe-emodin affected the release of apoptosis-inducing factor and cytochrome $c$ (cyt. $c$ ) from mitochondria, followed by activation of caspase-3, leading to DNA fragmentation, nuclear shrinkage, and apoptosis. The exposure of colon carcinoma cells to aloe-emodin suppressed the casein kinase II activity in a time-dependent manner, and this was accompanied by a reduced phosphorylation of Bid, a downstream substrate of casein kinase II and a proapoptotic molecule. These findings indicate that the inhibition of casein kinase II activity, the release of apoptosis-inducing factor and cyt. $c$ and caspase- 3 activation are involved in 
Fig. 16 Evolution of the number of publications per year

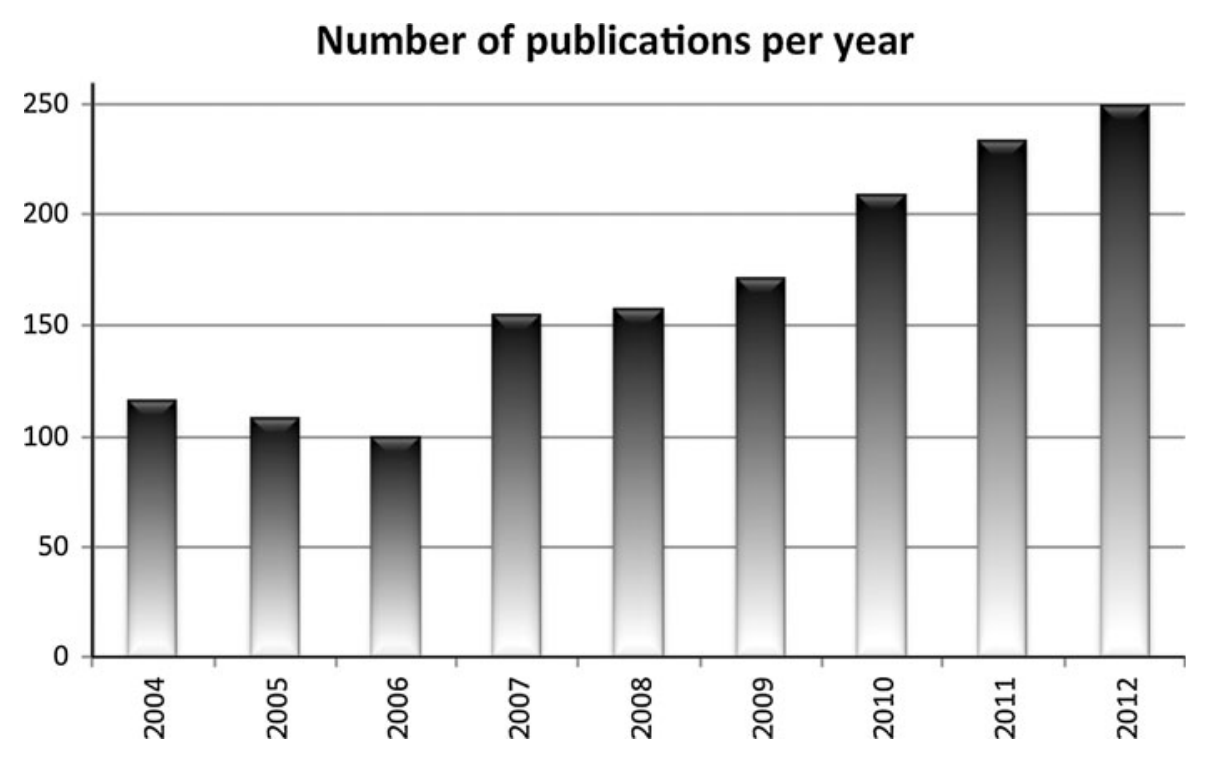

Number of publications per year

Anti-inflammatory effects

aloe-emodin-mediated apoptosis in colon carcinoma cells.

The results of several studies in vivo show that aloeemodin selectively inhibits human neuroectodermal tumor cell growth in tissue cultures and in animal models. In these cases, aloe-emodin was shown to be selectively toxic against neuroectodermal tumors and to inhibit human neuroectodermal tumor growth in an animal model with no evidence of acute or chronic toxicity. The lack of toxicity in combination with significant antitumor activity results in a favorable therapeutic index (Pecere et al. 2000).

The activity of mixtures of extracts and compounds has also been evaluated. An extract of A. barbadensis was examined for its cellular toxicity on HepG2 cells. The results show that aloe vera extracts induce HepG2 apoptosis by ATP depletion-related impairment of mitochondria, which is caspase-independent (Kim and Kwon 2006). The potential anticancer properties and modulatory effect of selected aloe vera active compounds on antioxidant enzyme activities were tested. Thus, three anthraquinones, aloesin, aloe-emodin and aloin, were extracted from aloe vera leaves. These three compounds, along with an N-terminal octapeptide derived from verectin (a biologically active $14 \mathrm{kDa}$ glycoprotein present in aloe vera), were tested for their relative antitumor efficacy in vivo. It was found that the active compounds exhibited significant prolongation of the life span of tumor-transplanted animals in the following order: barbaloin (aloin) $>$ octapeptide $>$ aloesin $>$ aloe-emodin (El-Shemy et al. 2010).
The anti-inflammatory effect of aloe vera is certainly the most widely observed (Davis et al. 1989; Adler et al. 1995; Vazquez et al. 1996; Reynolds and Dweck 1999; Bassetti and Sala 2001). Inflammation is a complex reaction of the body and it involves various metabolic pathways and various agents. The mechanisms by which aloe extracts exert anti-inflammatory effects are multiple, and several distinct pathways have been described. For example, some evidence suggests that the activity is due to gibberellins. Thus, the anti-inflammatory activities of aloe vera and gibberellin were measured in streptozotocin-induced diabetic mice by measuring the inhibition of polymorphonuclear leukocyte infiltration into a site of gelatin-induced inflammation (Davis and Maro 1989). Both aloe and gibberellin inhibited inflammation to a similar extent in a dose-response manner. These data were interpreted as suggesting that gibberellin or a gibberellin-like substance is an active anti-inflammatory component in aloe vera.

A second possible mechanism may involve complement depletion. Thus, an aqueous extract of aloe vera gel was fractionated into high (h-Mr) and low (1-Mr) molecular weight fractions by dialysis. Subsequent fractionation generated two fractions with molecular weights of 320 and $200 \mathrm{kDa}$. Preincubation of human pooled serum with these fractions resulted in a depletion of classical and alternative pathway complement activity. The inhibition appeared to be 
due to alternative pathway activation, resulting in consumption of C3 ('T Hart et al. 1989, 1990). The active fractions were mannose-rich polysaccharides.

A third possible mechanism may involve neutrophil emigration into inflamed tissues (Bowden 1995). The effect of some anti-inflammatory agents such as dexamethasone is related to a greater inhibition of neutrophil migration. The mode of action of these agents is related to the inhibitory action on the arachidonic acid pathway. An aqueous extract of aloe vera inhibited in vitro the conversion of arachidonic acid to prostaglandin $\mathrm{E}_{2}$ (PGE2), which suggests that the extract has cyclooxygenase inhibitory properties (Vazquez et al. 1996).

Numerous more recent studies in vivo have highlighted anti-inflammatory properties. For example, aloe vera extracts showed an inhibitory effect on the activity of partially purified lipoxygenase from the rat lung cytosol fraction. This antilipoxygenase activity could explain the anti-inflammatory properties, especially in applications for the healing of minor burns and skin ulcers (Bezakova et al. 2005).

Oral administration of $A$. barbadensis gel over 21 days significantly decreased the level of homocysteine and the level of folic acid was significantly elevated when compared to diabetic control in rats with alloxan-induced diabetes. The results suggest potent anti-inflammatory potential of A. barbadensis gel in experimental diabetes, meaning that aloe vera can be used as an alternative remedy for the treatment of diabetes mellitus and its complications (Vanitha et al. 2013). A chronic inflammatory state is a major pathogenesis of type 2 diabetes mellitus (Haffner 2006).

\section{Effect on the skin and wounds}

Besides the anti-inflammatory effect, the topical use of pure gel promotes healing and regeneration of the skin. Aloe vera gel act on fibroblasts, macrophages and epidermal cell activity, and it stimulates the formation of epidermal tissue, increases collagen synthesis and remodels and enhances tensile stress (Chithra et al. 1998).

Recent studies in vivo indicate that topical application of aloe vera leads to significantly faster wound healing and an increased amount of tissue repair. Such compounds can be applied as a topical treatment to accelerate the healing of surgically induced wounds in rats in comparison with other topical applications, such as thyroid hormone or silver sulfadiazine (Tarameshloo et al. 2012a, b).

Burning mouth syndrome (BMS) is manifested as a subjective burning sensation of the tongue, lips or entire oral cavity, but it does not show any visible lesions and there are no laboratory tests capable of accounting for the discomfort (Scala et al. 2003). In a clinical trial conducted on 75 patients diagnosed with this syndrome, the efficacy of aloe vera was evaluated in combination with a tongue protector and comparison was made with a placebo. The chronic nature and high prevalence of BMS meant that the condition was not resolved in the trial but the patients with severe pain passed to moderate pain, thus demonstrating a clinical improvement (Lopez-Jornet et al. 2013).

In an effort to exploit the beneficial properties of this plant on the skin, recent studies have focused on the feasibility of creating membranes for use as dressings for wounds (Khoshgozaran-Abras et al. 2012; Silva et al. 2013).

\section{Antibacterial activity}

The antibacterial activity of $A$. barbadensis was tested on several pathogens and the results showed that aloe vera could be recommended for the treatment of various bacterial diseases in the future. The leaf of this plant can be divided into gel and peel. These biological and toxicological effects have been widely studied in aloe vera gel while there is still little information on the uses of the peel, which is usually discarded as waste in the aloe industry (Kwon et al. 2011). Significant antimicrobial activities have been reported both in the inner gel and in the peel and further in vivo and in vitro studies should be carried out in order to enhance such properties of the gel and efforts should be made to identify the compounds responsible for the activity.

The antibacterial activity of aloe vera inner gel has been tested in Gram-positive and Gram-negative bacteria by several methods (Hamman 2008). In recent studies, extracts in different solvents such us hexane, chloroform, methanol and water of freezedried gel aloe powder were evaluated against Grampositive (Staphylococcus aureus, Enterococcus bovis) and Gram-negative (Shigella flexneri, Enterobacter cloacae) bacteria. These experiments show lower MIC (minimum inhibitory concentration) values for aloe 
vera gel than for the aqueous extract (Habeeb et al. 2007).

In another study, aloe vera gel has recently been explored as an edible coating in order to reduce the loss of post-harvest fruit quality in papaya. The antimicrobial effects of aloe gel were compared with those of the natural polysaccharide chitosan (an established coating material with antifungal activity). Fresh papaya fruits were coated with aloe gel, $50 \%$ aloe gel, papaya leaf extract (it is a potential antifungal agent), papaya leaf extract with aloe gel (1:1) and with $2.5 \%$ of chitosan. The coated and uncoated samples were stored at $30{ }^{\circ} \mathrm{C}$ and $42-55 \%$ relative humidity for 15 days. These assays showed that the coated fruits survived the storage period, while uncoated controls decayed within 10 days. Moreover, the effectiveness of the aloe gel coating was improved on incorporation of papaya leaf extract (Marpudi et al. 2011). These preservation technologies have been used for other fruits such as table grapes (Valverde et al. 2005; Serrano et al. 2006), mangoes (Dang et al. 2008), nectarines (Ahmed et al. 2009), apples (Song et al. 2013) and kiwis (Benítez et al. 2013).

Moreover, the antimicrobial activity was studied for ethanol, methanol and acetone extracts of aloe vera gel powder against four Gram-positive (Bacillus cereus, Bacillus subtilis, S. aureus, Streptococcus pyogenes) and Gram-negative (Escherichia coli, Pseudomonas aeruginosa, Salmonella typhi, Klebsiella pneumonia) bacteria using the agar well diffusion method. The ethanol and methanol extracts showed higher activity than the acetone extract against most of the tested pathogens (the first two had an inhibition zone between 12.66 and $23.33 \mathrm{~mm}$ and the maximum value was obtained for $B$. cereus). Nevertheless, the inhibition zone obtained on using the acetone extract ranged from 6.00 (for E.coli) to $7.33 \mathrm{~mm}$ (for $S$. pyogenes) and activity was not observed for $P$. aeruginosa and S. typhi. Generally, these extracts showed better activity against Gram-positive bacteria (Lawrence et al. 2009).

Regarding the activity of aloe vera peel, Kwon et al. evaluated the activity of the aqueous extract against Gram-positive (S. aureus, Bacillus spp., Enterococcus spp.) and Gram-negative (E. coli, Salmonella typhimurium, Pseudonomas aeruginosa, Vibrio vulnificus and Vibrio parahaemolyticus) bacteria. The best antimicrobial activity was shown against $E$. coli and Vibrio spp. Moreover, an in vivo study was carried out on mice challenged with $S$. typhimurium DT104. Fecal shedding of this bacteria significantly decreased and intestinal Salmonella specific IgA and IgG titers increased in mice fed with peel extracts (Kwon et al. 2011). In another study, aqueous, ethanolic and acetone extracts of aloe peel were analyzed against $S$. aureus, $S$. pyogenes, $P$. aeruginosa and $E$. coli. The maximum antibacterial activity was observed in the acetone extract and maximum growth suppression was observed in $S$. pyogenes and $P$. aeruginosa. When antifungal activity was evaluated against Aspergillus flavus and Aspergillus niger, the best results were also observed for the acetone extract (Arunkumar and Muthuselvam 2009).

Analogously, Pandey et al. evaluated the antibacterial activity of aqueous and ethanolic extracts of aloe peel against Gram-positive (E. bovis and S. aureus) and Gram-negative (E. coli, Proteus vulgaris, Proteus mirabilis, P. aeruginosa, Morganella morganii and Klebsiella pneumoniae) bacteria. The ethanolic extract showed great inhibitory effects for Grampositive bacteria E. bovis, while among Gram-negative bacteria the highest inhibitory effect was observed in $P$. aeruginosa. However, minimum inhibition concentrations were very low for both Gram-positive and Gram-negative bacteria (Pandey and Mishra 2010).

Immunomodulatory activity

A number of studies indicated immunomodulating activities of the polysaccharides in aloe vera gel and suggested that these effects occur via activation of macrophage cells to generate nitric oxide, secrete cytokines and present cell surface markers (Zhang and Tizard 1996; Chow et al. 2005; Im et al. 2005; Farahnejad et al. 2011). Some immune reactions that seem to be specific for acemannan as compared to other polysaccharides include stimulation of the antigenic response of human lymphocytes as well as the formation of all types of leucocytes from both spleen and bone marrow in irradiated mice. However, some other immunomodulation effects were shown to be linked to glycoproteins, namely lectins, found in aloe gel (Reynolds and Dweck 1999).

In another study it was shown that relatively high concentrations of acemannan are required to achieve modest activation of macrophages compared to crude aloe vera juice, which suggests that there is another 
component in the juice responsible for the macrophage activation. Further investigations revealed that although this component is present only in small amounts, its potency in terms of macrophage stimulation accounted fully for the activity obtained for the crude aloe vera juice (Pugh et al. 2001).

Recent studies have shown the effect of aloe vera gel extract and its isolated fractions on peritoneal macrophages against Candida albicans infection (Farahnejad et al. 2011). C. albicans is one of the most frequent pathogens among the medically important Candida species and it causes severe candidiasis in immunocompromised patients (Garber 2001). The results indicate that aloe vera gel extract induces macrophage cell viability against $C$. albicans. This study also indicated that the fraction that contains high molecular weight components, which encompasses acemannan (MW $>100 \mathrm{kDa}$ ), is the most effective fraction of aloe vera.

Furthermore, in this case the activity against human immunodeficient virus type 1 (HIV-1) would be remarkable. Aloe vera gel included in nutritional supplements was used in a clinical trial with these patients and it showed beneficial results (Pulse and Uhlig 1990). Previous studies carried out with acemannan showed a $71 \%$ reduction in symptoms of AIDS patients, probably due to stimulation of the immune system (Reynolds and Dweck 1999).

Obesity, cholesterol and anti-diabetic activity

Obesity is a condition in which an excess accumulation of body fat is caused by an imbalance of energy intake and expenditure, in addition to genetic background. Obesity, especially visceral fat obesity, is strongly associated with the development of metabolic syndrome, which includes insulin resistance, type 2 diabetes mellitus, hypertension, dyslipidemia and cardiovascular disease (Alberti et al. 2005). The prevalence of obesity is currently one of the most serious health problems around the world (Misawa et al. 2012). Aloe vera has been used as a folk remedy in many cultures to treat diabetes (Vogler and Ernst 1999; Yeh et al. 2003). Several clinical and experimental studies have demonstrated the hypoglycemic effects of aloe vera (Fugh-Berman 2000; Low 2006; Tapsell et al. 2006). Additionally, several reports on aloe vera-derived extracts showed a preventive effect against insulin resistance (Tundis et al. 2010) and a lipid-lowering effect (Vogler and Ernst 1999). From these observations, it is expected that aloe vera could be beneficial for the prevention or improvement of metabolic syndrome-related disorders.

The in vivo antidiabetic effects of the plant were investigated using streptozotocin-induced type 2 diabetic model rats (Moniruzzaman et al. 2012) and the hypolipedemic and antioxidant effects were also assessed. The ethanolic skin extracts of aloe vera were observed to contain the highest total phenolic and flavonoid contents. Furthermore, these extracts exhibited high DPPH scavenging activities and FRAP values, indicating the potential of this plant to be used as an antioxidant. Aloe vera extracts also have the potential to be used as hypoglycemic agents, especially the skin extract. Additionally, although the result is not statistically significant, the ethanol skin extract exhibited potent hypolipedemic effects by decreasing the serum cholesterol and LDL levels by 25 and $69 \%$, respectively, while the HDL levels also increased.

In other tests related to diabetes, leaf extracts in hexane, chloroform, acetone, methanol and water were evaluated at a dose of $100 \mathrm{mg} / \mathrm{kg}$ during 15 days. The results show that the aqueous extract of the leaves of aloe vera has potential for its antidiabetic activity, with the blood sugar levels in albino rats reduced by $48 \%$ at the 15th day (Maithani et al. 2011).

The effects of the oral administration of lophenol (Lo) and cycloartanol (Cy), two kinds of antidiabetic phytosterol isolated from aloe vera, have also been evaluated on glucose and lipid metabolism in Zucker diabetic fatty (ZDF) rats (Misawa et al. 2012). It was demonstrated that the administrations of Lo and Cy suppressed random and fasting glucose levels and reduced visceral fat weights significantly. It was also observed that treatments with Lo and Cy decreased serum and hepatic lipid concentrations (triglyceride, nonesterified fatty acid and total cholesterol). Additionally, Lo and Cy treatments resulted in a tendency for the reduction in the serum monocyte chemotactic protein-1 (MCP-1) level and an elevation in serum adiponectin level. Furthermore, the expression levels of hepatic genes encoding gluconeogenic enzymes (G6 Pase, PEPCK), lipogenic enzymes (ACC, FAS) and SREBP-1 were decreased significantly by the administration of aloe sterols. In contrast, Lo and Cy administration increased mRNA levels of glycolysis enzyme (GK) in the liver. It was also observed that the 
hepatic $\beta$-oxidation enzymes (ACO, CPT1) and PPAR $\alpha$ expressions tended to increase in the livers of the Lo- and Cy-treated rats compared with those in ZDF-control rats. It was therefore concluded that orally ingested aloe sterols altered the expressions of genes related to glucose and lipid metabolism and ameliorated obesity-associated metabolic disorders in ZDF rats. These findings suggest that aloe sterols could be beneficial in preventing and improving metabolic disorders with obesity and diabetes in rats.

\section{Laxative effects}

Constipation is a highly prevalent and often chronic functional gastrointestinal disorder affecting humans irrespective of race and color, with victims exposed to the risk of colorectal cancer. Although the traditional use of aloe vera as a laxative is known, little scientific evidence is available in the literature on the purgative potential of this plant.

The laxative activity of aloe vera has mainly been attributed to the anthraquinones (mainly aloin) present in the yellow exudates of the leaves (Tan et al. 2012). This anthraquinone, which is poorly absorbed from the GIT, is cleaved by gut bacteria to produce aloeemodin, which is more readily absorbed and is responsible for the purgative properties of aloe vera (Steenkamp and Stewart 2007). The laxative effect is believed to take place through water accumulation in the intestine via active $\mathrm{Na}^{+}$transport (Ishi et al. 1990) or by water secretion due to a prostaglandin-dependent mechanism (Capasso et al. 1983).

There are studies in which the laxative effect of this plant has been demonstrated in vivo. Thus, the laxative potential of the ethanolic leaf extract of aloe vera has been tested in Wistar rats with loperamide-induced constipation (Ashafa et al. 2011). Treatment of the rats with the extract at 50,100 and $200 \mathrm{mg} / \mathrm{kg}$ body weight for 7 days improved intestinal motility, increased fecal volume and normalized body weight in the constipated rats. There are indications of the laxative properties of the herb, with a level of $200 \mathrm{mg} / \mathrm{kg}$ body weight of the extract showing the best efficacy.

\section{Conclusions}

The beneficial effects of $A$. barbadensis are universally accepted nowadays. In this overview an in-depth knowledge of the history, composition and action of these plants was obtained from the recent literature. It is worth emphasizing the number of historical references concerning this plant. Throughout the centuries Aloe vera has been considered to be a magic plant that and has been capable of solving numerous human infirmities. In recent decades, detailed investigations have allowed us to summarize the characteristics of this plant, which seems to hide its secrets behind botanical and pharmacological mysteries and today many more responses are being uncovered.

Many analyses have been carried out on aloes in search of constituents that might be responsible for the beneficial properties and various new organic compounds, in addition to those described above, are reported from time to time.

It is clear that these biological effects have been widely studied in aloe vera gel but there is little information on the exploitation of the peel, which is usually discarded as waste in the aloe industry. Significant activities have been reported and efforts have been made to enhance the properties of the gel and to identify the compounds responsible for the activity. Numerous bioactivity studies have been carried out on the application of extracts in water and organic solvents from the gel and leaf peel, but it is noteworthy that synergistic effects have barely been investigated. Thus, a great deal of effort must be invested in order to obtain further information on these effects for different compounds.

At present almost $80 \%$ of the publications on Aloe vera are in the area of medicine and pharmacology, followed by agriculture, biochemistry and chemistry. These new natural compounds are expanding our treatment choices for the management of different disorders on an ongoing basis, with new and different uses and research data supporting their prestige as safe and effective options.

Acknowledgments This work was supported by the Consejería de Innovación, Ciencia y Empresa, Junta de Andalucía (Project P10-AGR5822).

\section{References}

Acevedo-Duncan M, Russell C, Patel S, Patel R (2004) Aloeemodin modulates PKC isozymes, inhibits proliferation, and induces apoptosis in U-373MG glioma cells. Int Immunopharmacol 4:1775-1784 
Adler H, Frech B, Thoeny M, Pfister H, Peterhans E, Jungi TW (1995) Inducible nitric oxide synthase in cattle. Differential cytokine regulation of nitric oxide synthase in bovine and murine macrophages. J Immunol 154:4710-4718

Ahmed MJ, Singh Z, Khan AS (2009) Postharvest Aloe vera gelcoating modulates fruit ripening and quality of 'Arctic snow' nectarine kept in ambient and cold storage. Int J Food Sci Technol 44:1024-1033

Alberti KGMM, Zimmet P, Shaw J (2005) The metabolic syndrome-a new worldwide definition. Lancet 366: 1059-1062

Arunkumar S, Muthuselvam M (2009) Analysis of phytochemical constituents and antimicrobial activities of Aloe vera $\mathrm{L}$. against clinical pathogens. World J Agric Sci 5: $572-576$

Ashafa AT, Abass A A, Sunmonu TO, Ogbe A A (2011) Laxative potential of the ethanolic leaf extract of Aloe vera (L.) Burm. f. in Wistar rats with loperamide-induced constipation. J Nat Pharm 2:158

Ashnagar A, Naseri NG, Heidarzadeh A (2006) Isolation and identification of the major chemical compounds found in the extracts of the leaves of Aloe vera plant. Int J Chem Sci 4:1025-1030

Bassetti A, Sala S (2001) El gran libro del Aloe. Ediciones Zuccari, Trento

Benítez S, Achaerandio I, Sepulcre F, Pujolà M (2013) Aloe vera based edible coatings improve the quality of minimally processed 'Hayward' kiwifruit. Postharvest Biol Technol 81:29-36

Bezakova L, Oblozinsky M, Sykorova M, Paulikova I, Kostalova D (2005) Antilipoxygenase activity and the trace elements content of Aloe vera in relation to the therapeutical effect. Ceska Slov Farm 54:43-46

Boudreau MD, Beland FA (2006) An evaluation of the biological and toxicological properties of Aloe barbadensis (Miller) aloe vera. J Environ Sci Health C Environ Carcinog Ecotoxicol Rev 24:103-154

Bowden RA (1995) The effect of a mannose-rich extract on integrin expression on vascular endothelial cells. Texas A\&M University, Houston

Capasso F, Mascolo N, Autore G, Duraccio MR (1983) Effect of indomethacin on aloin and 1,8 dioxianthraquinone-induced production of prostaglandins in rat isolated colon. Prostaglandins 26:557-562

Carter S (1994) Aloaceae. In: Polhill RM (ed). Balkema, Rotterdam

Chithra P, Sajithlal GB, Chandrakasan G (1998) Influence of aloe vera on the healing of dermal wounds in diabetic rats. J Ethnopharmacol 59:195-201

Choi J-S, Lee S-K, Sung C-K, Jung J-H (1996) Phytochemical study on Aloe vera. Arch Pharmacal Res 19:163-167

Chow JT-N, Williamson DA, Yates KM, Goux WJ (2005) Chemical characterization of the immunomodulating polysaccharide of Aloe vera L. Carbohydr Res 340: $1131-1142$

Conner JM, Gray AI, Waterman PG, Reynolds T (1990) Novel anthrone-anthraquinone dimers from Aloe elgonica. J Nat Prod 53:1362-1364

Dang KTH, Singh Z, Swinny EE (2008) Edible coatings influence fruit ripening, quality, and aroma biosynthesis in mango fruit. J Agric Food Chem 56:1361-1370
Davis RH, Maro NP (1989) Aloe vera and gibberellin. Antiinflammatory activity in diabetes. J Am Podiatr Med Assoc 79:24-26

Davis RH, Leitner MG, Russo JM, Byrne ME (1989) Antiinflammatory activity of Aloe vera against a spectrum of irritants. J Am Podiatr Med Assoc 79:263-276

DiscoverLife (2013) http://www.discoverlife.org/. August 2013

El-Shemy HA, Aboul-Soud MAM, Nassr-Allah AA, AboulEnein KM, Kabash A, Yagi A (2010) Antitumor properties and modulation of antioxidant enzymes activity by Aloe vera leaf active principles isolated via supercritical carbon dioxide extraction. Curr Med Chem 17:129-138

Evans WC (1989) Trease and Evans' pharmacology. 13th edn/ ed., Boilliere Tindall, London

Fanali S, Aturki Z, D’Orazio G, Rocco A, Ferranti A, Mercolini L, Raggi MA (2010) Analysis of Aloe-based phytotherapeutic products by using nano-LC-MS. J Sep Sci 33: 2663-2670

Farahnejad Z, Ghazanfari T, Yaraee R (2011) Immunomodulatory effects of Aloe vera and its fractions on response of macrophages against Candida albicans. Immunopharmacol Immunotoxicol 33:676-681

Femenia A, Sanchez ES, Simal S, Rossello C (1999) Compositional features of polysaccharides from Aloe vera (Aloe barbadensis Miller) plant tissues. Carbohydr Polym 39: 109-117

Fugh-Berman A (2000) Herbs and dietary supplements in the prevention and treatment of cardiovascular disease. Prev Cardiol 3:24-32

Garber G (2001) An overview of fungal infections. Drugs 61(Suppl 1):1-12

Gowda DC, Neelisiddaiah B, Anjaneyalu YV (1979) Structural studies of Polysaccharides from Aloe-vera. Carbohydr Res 72:201-205

Grieve M (1998) A modern herbal. Tiger Books International, London

Grindlay D, Reynolds T (1986a) The Aloe-vera phenomenona review of the properties and modern uses of the leaf parenchyma gel. J Ethnopharmacol 16:117-151

Grindlay D, Reynolds T (1986b) The Aloe vera phenomenon: a review of the properties and modern uses of the leaf parenchyma gel. J Ethnopharmacol 16:117-151

Habeeb F, Shakir E, Bradbury F, Cameron P, Taravati MR, Drummond AJ, Gray AI, Ferro VA (2007) Screening methods used to determine the anti-microbial properties of Aloe vera inner gel. Methods (Oxford, UK) 42:315-320

Haffner SM (2006) The metabolic syndrome: inflammation, diabetes mellitus, and cardiovascular disease. Am J Cardiol 97:3A-11A

Hamman JH (2008) Composition and applications of Aloe vera leaf gel. Molecules 13:1599-1616

Harlev E, Nevo E, Lansky EP, Ofir R, Bishayee A (2012) Anticancer potential of aloes: antioxidant, antiproliferative, and immunostimulatory attributes. Planta Med 78: 843-852

Harris C, Pierce K, King G, Yates KM, Hall J, Tizard I (1991) Efficacy of acemannan in treatment of canine and feline spontaneous neoplasms. Mol Biother 3:207-213

Haynes LJ, Holdsworth DK, Russell R (1970) C-glycosyl compounds. Part VI. Aloesin, a C-glucosylchromone from Aloe sp. J Chem Soc C Org 18:2581-2586 
Holdsworth DK (1972) Chromones in aloe species. II. Aloesone. Planta Med. 22:54-58

Hranisavljevic-Jakovljevic M, Miljkovic-Stojanovic J (1981) Structural study of an acidic polysaccharide isolated from Aloe arborescens Mill. I. Periodate oxidation and partial acid hydrolysis. Glas Hem Drus Beogr 46:269-273

Hsu S-C, Chung J-G (2012) Anticancer potential of emodin. BioMedicine (Taipei, Taiwan) 2:108-116

Ian T, Yawei N (2004) Aloe polysaccharides. In: Reynolds T (ed) Aloes the genus Aloe. CRC Press, Bocaraton, FL, pp 75-87

Im S-A, Oh S-T, Song S, Kim M-R, Kim D-S, Woo S-S, Jo TH, Park YI, Lee C-K (2005) Identification of optimal molecular size of modified Aloe polysaccharides with maximum immunomodulatory activity. Int Immunopharmacol 5:271-279

Ishi Y, Tanizawa H, Takino Y (1990) Studies of aloe. III. Mechanism of cathartic effect. (2). Chem Pharm Bull 38: 197-200

Khoshgozaran-Abras S, Azizi MH, Hamidy Z, BagheripoorFallah N (2012) Mechanical, physicochemical and color properties of chitosan based-films as a function of Aloe vera gel incorporation. Carbohydr Polym 87:20582062

Kim I, Kwon H (2006) Induction of apoptosis by Aloe vera extract in human hepatocellular carcinoma HepG2 cells. J Toxicol Public Health 22:329-332

Kinoshita K, Koyama K, Takahashi K, Noguchi Y, Amano M (1996) Steroid glucosides from Aloe barbadensis. J Jpn Botany 71:83-86

Kwon KH, Hong MK, Hwang SY, Moon BY, Shin S, Baek JH, Park YH (2011) Antimicrobial and immunomodulatory effects of Aloe vera peel extract. J Med Plants Res 5:5384-5392

Lawrence R, Tripathi P, Jeyakumar E (2009) Isolation, purification and evaluation of antibacterial agents from Aloe vera. Braz J Microbiol 40:906-915

Lee S, Do S-G, Kim SY, Kim J, Jin Y, Lee CH (2012) Mass spectrometry-based metabolite profiling and antioxidant activity of Aloe vera (Aloe barbadensis Miller) in different growth stages. J Agric Food Chem 60:11222-11228

Lin K-Y, Uen Y-H (2010) Aloe-emodin, an anthraquinone, in vitro inhibits proliferation and induces apoptosis in human colon carcinoma cells. Oncol Lett 1:541-547

Lopez A, de Tangil MS, Vega-Orellana O, Ramirez AS, Rico M (2013) Phenolic constituents, antioxidant and preliminary antimycoplasmic activities of leaf skin and flowers of Aloe vera (L.) Burm. f. (syn. A. barbadensis Mill.) from the Canary Islands (Spain). Molecules 18:4942-4954

Lopez-Jornet P, Camacho-Alonso F, Molino-Pagan D (2013) Prospective, randomized, double-blind, clinical evaluation of Aloe vera Barbadensis, applied in combination with a tongue protector to treat burning mouth syndrome. J Oral Pathol Med 42:295-301

Low DT (2006) A reason to season: the therapeutic benefits of spices and culinary herbs. Explore (NY) 2:446-449

Lv L, Yang Q-Y, Zhao Y, Yao C-S, Sun Y, Yang E-J, Song K-S, Mook-Jung I, Fang W-S (2008) BACE1 ( $\beta$-secretase) inhibitory chromone glycosides from Aloe vera and Aloe nobilis. Planta Med 74:540-545
Mabusela WT, Stephen AM, Botha MC (1990) Carbohydrate polymers from Aloe ferox leaves. Phytochemistry 29: 3555-3558

Maithani A, Parcha V, Pant G, Dhulia I, Kumar D (2011) Studies on phytochemical screening and hypoglycemic evaluation of Aloe vera leave extracts on alloxan induced diabetic rats. Int J Res Phytochem Pharmacol 1:207-210

Mandal G, Das A (1980a) Characterization of the polysaccharides of Aloe barbadensis Miller. Part II. Structure of the glucomannan isolated from the leaves of Aloe barbadensis Miller. Carbohydr Res 87:249-256

Mandal G, Das A (1980b) Characterization of the polysaccharides of Aloe barbadensis. Part I. Structure of the D-galactan isolated from Aloe barbadensis Miller. Carbohydr Res 86:247-257

Manna S, McAnalley BH (1993) Determination of the position of the $O$-acetyl group in a beta- $(1 \rightarrow 4)$-mannan (acemannan) from Aloe barbardensis Miller. Carbohydr Res 241:317-319

Marpudi SL, Abirami LSS, Pushkala R, Srividya N (2011) Enhancement of storage life and quality maintenance of papaya fruits using Aloe vera based antimicrobial coating. Indian J Biotechnol 10:83-89

McMahon M, Regan F, Hughes H (2006) The determination of total germanium in real food samples including Chinese herbal remedies using graphite furnace atomic absorption spectroscopy. Food Chem 97:411-417

Meng I, Yang BZ, Hu G, Lu Y, Liu Y (2004) Determination of components of anthraquinones in Aloe vera. Beijing $\mathrm{Hu}-$ agong Daxue Xuebao Ziran Kexueban 31:70-73

Misawa E, Tanaka M, Nomaguchi K, Nabeshima K, Yamada M, Toida T, Iwatsuki K (2012) Oral ingestion of Aloe vera phytosterols alters hepatic gene expression profiles and ameliorates obesity-associated metabolic disorders in zucker diabetic fatty rats. J Agric Food Chem 60: 2799-2806

Moniruzzaman M, Rokeya B, Ahmed S, Bhowmik A, Khalil MI, Gan SH (2012) In vitro antioxidant effects of Aloe barbadensis Miller extracts and the potential role of these extracts as antidiabetic and antilipidemic agents on streptozotocin-induced type 2 diabetic model rats. Molecules $17: 12851-12867$

Newton LE (2001) Aloe. In: Eggli U (ed) Illustrated handbook of succulent plants: monocotyledons. Springer, Berlin

Ni Y, Turner D, Yates KM, Tizard I (2004) Isolation and characterization of structural components of Aloe vera $\mathrm{L}$. leaf pulp. Int Immunopharmacol 4:1745-1755

Niciforovic A, Adzic M, Zaric B, Radojcic MB (2007) Adjuvant antiproliferative and cytotoxic effect of aloin in irradiated HeLaS3 cells. Russ J Phys Chem A 81:1463-1466

Okamura N, Hine N, Harada S, Fujioka T, Mihashi K, Yagi A (1996) Three chromone components from Aloe vera leaves. Phytochemistry 43:495-498

Okamura N, Hine N, Harada S, Fujioka T, Mihashi K, Nishi M, Miyahara K, Yagi A (1997a) Diastereomeric C-glucosylanthrones of Aloe vera leaves. Phytochemistry 45: $1519-1522$

Okamura N, Hine N, Tateyama Y, Nakazawa M, Fujioka T, Mirmhi K, Yagi A (1997b) Three chromones of Aloe vera leaves. Phytochemistry 45:1511-1513 
Okamura N, Hine N, Tateyama Y, Nakazawa M, Fujioka T, Mihashi K, Yagi A (1998) Five chromones from Aloe Vera leaves. Phytochemistry 49:219-223

Ovodova RG, Lapchik VF, Ovodov YS (1975) Polysaccharides of Aloe arborescens. Khim Prir Soedin 11:3-5

Pandey R, Mishra A (2010) Antibacterial activities of crude extract of Aloe barbadensis to clinically isolated bacterial pathogens. Appl Biochem Biotechnol 160:1356-1361

Park MK, Park JH, Shin YG, Kim WY, Lee JH, Kim KH (1996) Neoaloesin A. A new C-glucofuranosyl chromone from Aloe barbadensis. Planta Med 62:363-365

Park MK, Park JH, Kim NY, Shin YG, Choi YS, Lee JG, Kim KH, Lee SK (1998) Analysis of 13 phenolic compounds in Aloe species by high performance liquid chromatography. Phytochem Anal 9:186-191

Patel DK, Patel K, Tahilyani V (2012) Barbaloin: a concise report of its pharmacological and analytical aspects. Asian Pac J Trop Biomed 2:835-838

Paulsen BS, Fagerheim E, Oeverbye E (1978) Structural studies of the polysaccharide from Aloe plicatilis Miller. Carbohydr Res 60:345-351

Pecere T, Gazzola MV, Mucignat C, Parolin C, Dalla VF, Cavaggioni A, Basso G, Diaspro A, Salvato B, Carli M, Palu G (2000) Aloe-emodin is a new type of anticancer agent with selective activity against neuroectodermal tumors. Cancer Res 60:2800-2804

Pugh N, Ross SA, ElSohly MA, Pasco DS (2001) Characterization of Aloeride, a new high-molecular-weight polysaccharide from Aloe vera with potent immunostimulatory activity. J Agric Food Chem 49:1030-1034

Pulse TL, Uhlig E (1990) A significant improvement in a clinical pilot study utilizing nutritional supplements, essential fatty acids and stabilized aloe vera juice in 29 HIV seropositive, ARC and AIDS patients. J Adv Med 3:209-230

Radjabi-Nassab F, Ramiliarison C, Monneret C, Vilkas E (1984) Further studies of the glucomannan from Aloe vahombe (liliaceae). II. Partial hydrolyses and NMR carbon-13 studies. Biochimie 66:563-567

Ramachandra CT, Srinivasa Rao P (2008) Processing of Aloe vera leaf gel: a review. Am J Agric Biol Sci 3:502-510

Rauwald HW (1990) Naturally occurring quinones and their related reduction forms: analysis and analytical methods. PZ Wiss 3:169-181

Rauwald HW, Niyonzima DD (1991) Free and cinnamoylated 8-O-methyl-7-hydroxyaloins from Aloe barbadensis: isolation, structure, and configurational determination of the diastereoisomers. Planta Med 57:A129. doi:10.1055/s2006-960426

Reynolds GW (1966) The aloes of tropical Africa and Madagascar. Aloes Book Fund, Mbabane

Reynolds T (1985) Observations on the phytochemistry of the Aloë leaf-exudate compounds. Bot J Linn Soc 90:179-199

Reynolds T (2004) Aloes: the genus Aloe. Medicinal and aromatic plants-industrial profiles. CPR Press, Boca Raton, FL

Reynolds T, Dweck AC (1999) Aloe vera leaf gel: a review update. J Ethnopharmacol 68:3-37

Robson MC, Heggers JP, Hagstrom WJ Jr (1982) Myth, magic, witchcraft, or fact? Aloe vera revisited. J Burn Care Rehabil 3:157-163

Rowe TD, Parks LM (1941) A phytochemical study of Aloe vera leaf. J Am Pharm Assoc (1912-1977) 30:262-266
Saccu D, Bogoni P, Procida G (2001) Aloe exudate: characterization by reversed phase HPLC and headspace GC-MS. J Agric Food Chem 49:4526-4530

Saleem R, Faizi S, Deeba F, Siddiqui BS, Qazi MH (1997) A new bisbenzopyran from Aloe barbadensis roots. Planta Med 63:454-456

Saleen R, Faizi S, Deeba F, Siddiqui BS, Qazi MH (1997) Anthrones from Aloe barbadensis. Phytochemistry 45: $1279-1282$

Scala A, Checchi L, Montevecchi M, Marini I, Giamberardino MA (2003) Update on burning mouth syndrome: overview and patient management. Crit Rev Oral Biol Med 14: 275-291

Schweizer M (1994) Aloe vera. La planta que cura. APB, Paris

Scopus (2013) http://www.scopus.com/. August 2013

Segal A, Taylor JA, Eoff JC (1968) A re-investigation of the polysaccharide material from Aloe vera mucilage. Lloydia 31:423

Serrano M, Valverde JM, Guillen F, Castillo S, Martinez-Romero D, Valero D (2006) Use of Aloe vera gel coating preserves the functional properties of table grapes. J Agric Food Chem 54:3882-3886

Sigler A, Rauwald HW (1994) First proof of anthrone aglycons and diastereomeric anthrone-C-glycosyls in flowers and bracts of Aloe species. Biochem Syst Ecol 22:287-290

Silva SS, Popa EG, Gomes ME, Cerqueira M, Marques AP, Caridade SG, Teixeira P, Sousa C, Mano JF, Reis RL (2013) An investigation of the potential application of chitosan/aloe-based membranes for regenerative medicine. Acta Biomater 9:6790-6797

Song H-Y, Jo W-S, Song N-B, Min SC, Song KB (2013) Quality change of apple slices coated with Aloe vera gel during storage. J Food Sci 78(6):C817-C822

Speranza G, Manitto P, Cassara P, Monti D (1993) Feralolide, a dihydroisocoumarin from Cape aloe. Phytochemistry 33: 175-178

Steenkamp V, Stewart MJ (2007) Medicinal applications and toxicological activities of Aloe. Products. Pharm Biol 45:411-420

Swanson LN (1995) Therapeutic value of aloe vera. US Pharmacy 20:26-35

Tan Z, Li F, Xu X (2012) Isolation and purification of aloe anthraquinones based on an ionic liquid/salt aqueous twophase system. Sep Purif Technol 98:150-157

Tanaka M, Misawa E, Ito Y, Habara N, Nomaguchi K, Yamada M, Toida T, Hayasawa H, Takase M, Inagaki M, Higuchi R (2006) Identification of five phytosterols from Aloe vera gel as anti-diabetic compounds. Biol Pharm Bull 29: $1418-1422$

Tapsell LC, Hemphill I, Cobiac L, Patch CS, Sullivan DR, Fenech M, Roodenrys S, Keogh JB, Clifton PM, Williams PG, Fazio VA, Inge KE (2006) Health benefits of herbs and spices: the past, the present, the future. Med J Aust 185:S4 S24

Tarameshloo M, Norouzian M, Zarein-Dolab S, Dadpay M, Gazor R (2012a) A comparative study of the effects of topical application of Aloe vera, thyroid hormone and silver sulfadiazine on skin wounds in Wistar rats. Lab Anim Res 28:17-21

Tarameshloo M, Norouzian M, Zarein-Dolab S, Dadpay M, Mohsenifar J, Gazor R (2012b) Aloe vera gel and thyroid 
hormone cream may improve wound healing in Wistar rats. Anat Cell Biol 45:170-177

'T Hart LA, van den Berg AJ, Kuis L, van Dijk H, Labadie RP (1989) An anti-complementary polysaccharide with immunological adjuvant activity from the leaf parenchyma gel of Aloe vera. Planta Med 55:509-512

'T Hart LA, Nibbering PH, van den Berselaar MT, van Dijk H, van den Berg AJ, Labadie RP (1990) Effects of low molecular constituents from Aloe vera gel on oxidative metabolism and cytotoxic and bactericidal activities of human neutrophils. Int J Immunopharmacol 12:427-434

Tizard IR, Ramamoorthy L (2004) Aloes and the immune system. In: Tom Reynolds (ed) Medicinal aromatic plants-industrial profiles, vol. 38. CRC Press, Boca Raton, pp 311-332

Tundis R, Loizzo MR, Menichini F (2010) Natural products as $\alpha$-amylase and $\alpha$-glucosidase inhibitors and their hypoglycaemic potential in the treatment of diabetes: an update. Mini Rev Med Chem 10:315-331

Valverde JM, Valero D, Martinez-Romero D, Guillen F, Castillo S, Serrano M (2005) Novel edible coating based on Aloe vera gel to maintain table grape quality and safety. J Agric Food Chem 53:7807-7813

Vanitha M, Suja Pandian R, Karthikeyan J (2013) Evaluation of aloevera gel for its anti inflammatory activity in diabetes mellitus using animal model system. Int J Drug Dev Res 5:305-309

Vazquez B, Avila G, Segura D, Escalante B (1996) Antiinflammatory activity of extracts from Aloe vera gel. J Ethnopharmacol 55:69-75

Viljoen AM, van Wyk B-E, van Heerden FR (2002) The chemotaxonomic value of the diglucoside anthrone homonataloside B in the genus Aloe. Biochem Syst Ecol 30:35-43

Vilkas E, Radjabi-Nassab F (1986) The glucomannan system from Aloe vahombe (liliaceae). III. Comparative studies on the glucomannan components isolated from the leaves. Biochimie 68:1123-1127

Vinson JA, Al Kharrat H, Andreoli L (2005) Effect of Aloe vera preparations on the human bioavailability of vitamins $\mathrm{C}$ and E. Phytomedicine 12:760-765

Vogler BK, Ernst E (1999) Aloe vera: a systematic review of its clinical effectiveness. Br J Gen Pract 49:823-828

Waller GR, Mangiafico S, Ritchey CR (1978) A chemical investigation of Aloe barbadensis Miller. Proc Okla Acad Sci 58:69-76
Wozniewski T, Blaschek W, Franz G (1990) Isolation and structure analysis of a glucomannan from the leaves of Aloe arborescens var. Miller. Carbohydr Res 198:387-391

Wu X, Yin S, Zhong J, Ding W, Wan J, Xie Z (2012) Mushroom tyrosinase inhibitors from Aloe barbadensis Miller. Fitoterapia 83:1706-1711

Wu X, Ding W, Zhong J, Wan J, Xie Z (2013) Simultaneous qualitative and quantitative determination of phenolic compounds in Aloe barbadensis Mill by liquid chromatography-mass spectrometry-ion trap-time-of-flight and high performance liquid chromatography-diode array detector. J Pharm Biomed Anal 80:94-106

Xiao Z, Chen D, Si J, Tu G, Ma L (2000) Chemical constituents of Aloe vera. Yaoxue Xuebao 35:120-123

Yagi A, Makino K, Nishioka I, Kuchino Y (1977) Aloe-mannan, polysaccharide, from Aloe arborescens var natalensis. Planta Med 31:17-20

Yagi A, Hamada K, Mihashi K, Harada N, Nishioka I (1984) Structure determination of polysaccharides in Aloe saponaria (Hill.) Haw. (Liliaceae). J Pharm Sci 73:62-65

Yagi A, Nishimura H, Shida T, Nishioka I (1986) Structure determination of polysaccharides in Aloe arborescens var natalensis. Planta Med 3:213-218

Yagi A, Hine N, Asai M, Nakazawa M, Tateyama Y, Okamura N, Fujioka T, Mihashi K, Shimomura K (1998) Tetrahydroanthracene glucosides in callus tissue from Aloe barbadensis leaves. Phytochemistry 47:1267-1270

Yamaguchi I, Mega N, Sanada H (1993) Components of the gel of Aloe vera (L.) Burm. f. Biosci Biotechnol Biochem 57:1350-1352

Yang Q-Y, Yao C-S, Fang W-S (2010) A new triglucosylated naphthalene glycoside from Aloe vera L. Fitoterapia 81:59-62

Yau Y-h, Ho K-c, Xu J-1, Leung K-l, Leung Y-h (2011) Evaluation of two house plants for indoor air purification. Chengshi Huanjing Yu Chengshi Shengtai 24:1-4

Yeh GY, Eisenberg DM, Kaptchuk TJ, Phillips RS (2003) Systematic review of herbs and dietary supplements for glycemic control in diabetes. Diabetes Care 26:1277-1294

Zhang L, Tizard IR (1996) Activation of a mouse macrophage cell line by acemannan: the major carbohydrate fraction from Aloe vera gel. Immunopharmacology 35:119-128 